\title{
AMS DATING OF A LATE QUATERNARY TEPHRA AT GRAHAM'S TERRACE, NEW ZEALAND
}

\author{
RICHARD GILLESPIE ${ }^{1}$, A. P. HAMMOND ${ }^{2}$, K. M. GOH ${ }^{2}$, P. J. TONKIN ${ }^{2}$, D. C. LOWE 3 \\ R. J. SPARKS ${ }^{3}$ and GAVIN WALLACE ${ }^{3}$
}

\begin{abstract}
The radiocarbon dating of volcanic ash (tephra) deposits in New Zealand has been difficult on sites remote from the eruption, which contain either little carbon or degraded and contaminated charcoal. Although many studies of contamination removal from macroscopic charcoals from tephra sequences have been made, little attention has been paid to those containing no visible charcoal, because of the difficulty of obtaining sufficient carbon for radiometric dating. We report here experiments using accelerator mass spectrometry to establish a reliable method for dating a low-carbon aeolian and peat deposit containing a tephra horizon. Results so far demonstrate that improvements to existing chemical pretreatment methods are possible, and that dates obtained on oxidized fine-grained residues can approach the maximum age determined on good quality charred wood samples.
\end{abstract}

\section{INTRODUCTION}

The Graham's Terrace tephra site is about $9.5 \mathrm{~km}$ southeast of Nelson Creek township in the Grey River valley on the South Island of New Zealand (Grid Reference NZMS 260 K32/928588). Mew et al. (1986) described the site, and carried out extensive chemical and sedimentological analyses, concluding that the tephra is identical to a widely distributed volcanic ash deposit, variously called Kawakawa, Oruanui, Wairakei or Aokautere. The pooled mean age of four radiocarbon determinations, Q-2665 to -2668, made on carbonized wood fragments, found embedded in non-welded ignimbrite from a major eruption at Taupo in central North Island, New Zealand, is 22,590 \pm 230 BP. Other dates on materials associated with the same eruption, at both North and South Island sites, range from 20,550 \pm 300 to 21,300 $\pm 460 \mathrm{BP}$ (Wilson, Switsur \& Ward 1988). Acid-washed fine sandy loam from below the tephra layer at the Graham's Terrace site in north western South Island gave an age of 15,600 $\pm 250 \mathrm{BP}$ (NZ-6557, Mew et al. 1986). This discrepancy in ages for the supposedly same event gave initial impetus to the work reported here.

Previous work on macroscopic charcoal from Quaternary deposits in New Zealand have demonstrated that contamination by younger organic carbon is common and difficult to remove completely. Bailey and Lee (1972) and Bailey et al. (1975) used extraction with 0.5 mol sodium hydroxide, and concluded that the humic-acid fractions in their samples were not age-affecting contaminants, whereas Goh and Molloy (1972) demonstrated that extraction with alkali/ pyrophosphate was an effective pretreatment for charcoals. When using soil organic components for dating, in contrast to buried charcoals, Goh and Pullar (1977) showed that alkali/pyrophosphate extraction was not as effective as hydrolysis with either $6 \mathrm{~mol} \mathrm{HCl}$ or $72 \%$ sulfuric acid, and that solvent extraction also gave an increase in age. Goh, Molloy and Rafter (1977) found that the clayhumus fraction physically sorted from loess deposits was younger than charcoal from the same deposit. Goh (1978) and Hammond et al. (1991) concluded that 70\% nitric acid hydrolysis was the most effective treatment when soil organic components were used for dating, though in some soils, the amounts of carbon left for dating may be insufficient for conventional radiometric dating. According to Goh (1991), chemical pretreatments used for buried charcoals should be different from those used for soil organic components, because of the different nature of contamination in

\footnotetext{
${ }^{1}$ Department of Biogeography and Geomorphology, Australian National University, Canberra, ACT 2601 Australia

${ }^{2}$ Department of Soil Science, Lincoln University, Canterbury, New Zealand

${ }^{3}$ Nuclear Sciences Group, Department of Scientific and Industrial Research, Lower Hutt, New Zealand
} 
these materials. With the availability of accelerator mass spectrometry (AMS) technology, and the consequent small-sample capability allowing substantially improved chemical pretreatment, we approached the problem by dating all fractions from many different chemical extractions.

\section{SAMPLE PRETREATMENT}

All samples contained $4.5-5.5 \%$ organic carbon when analyzed by a chromate oxidation method (Schollenberger 1945). Before chemical pretreatment, samples of $c a .200 \mathrm{~g}$ were wet-sieved through a $63-\mu \mathrm{m}$ screen, and $10-20 \mathrm{~g}$ subsamples of the fine fraction were used for further work. In all cases, more than $95 \%$ by weight passed the $63-\mu \mathrm{m}$ screen. For the tephra layer itself, some fibrous material was retained on the sieve, and this was processed by standard methods for cellulose preparation $\left(5 \% \mathrm{NaClO}_{2}\right.$ in $\mathrm{pH} 3 \mathrm{HCl}$ at $\left.90^{\circ} \mathrm{C}\right)$. For the remaining fine-grained samples, two sets of pretreatment methodologies, and the data resulting from these, are described here - one set was carried out by A. P. Hammond and K. M. Goh at Lincoln University, the other set carried out by Richard Gillespie at the Australian National University (ANU).

The Lincoln University techniques follow more-or-less standard practices presently employed in New Zealand and elsewhere, for the radiocarbon dating of soils and sedimentary charcoals (Goh 1991). These methods employ dilute acid and alkali extractions, often called the acid/base/acid sequence, to remove fulvic- and humic-acid contaminants. This involves extraction of humic material with an alkaline solution containing 0.1 mol sodium hydroxide and tetrasodium pyrophosphate, with subsequent precipitation of the humic-acid component using concentrated hydrochloric acid. The fulvic acid remains in solution and may be recovered by evaporation or dialysis. Also used were strong acid treatments, such as 6 mol hydrochloric acid hydrolysis (Scharpenseel 1979), and 70\% nitric-acid hydrolysis (Shultz 1962). A graded-strength organic solvent extraction sequence, using acetone, petroleum spirit, ethanol/benzene and methanol/ chloroform under reflux conditions (Hance \& Anderson 1963), and the simpler technique of ultrasonic agitation in chloroform (Fowler, Gillespie \& Hedges 1986), were used for lipid extractions. We also used a pollen analysis preparation (N. Moar, personal communication 1988) with the sequence:

1. Boiling $10 \% \mathrm{KOH}$ solution

2. Wet sieving

3. Boiling $10 \% \mathrm{HCl}$

4. Digestion in hot $40 \% \mathrm{HF}$

5. Hypochlorite bleach

6. Acetolysis with hot concentrate $\mathrm{H}_{2} \mathrm{SO}_{4}$ /acetic anhydride.

At ANU, we explored techniques borrowed from those used to prepare samples for pollen analysis and fire history in Australia (Gray 1965; Clark 1983; Singh \& Geissler 1985). These chemical procedures are designed to remove most inorganic and organic materials except pollen and fine charcoal from fine-grained sediments. After some preliminary trials with samples from other sites (Gillespie et al. 1991), we developed the following pretreatment sequence:

1. Wet seive to pass $63 \mu \mathrm{m}$, acidify with $\mathrm{HCl}$ to $\sim \mathrm{pH} 1$, centrifuge and wash

2. Extraction with alkali (either hot $10 \% \mathrm{KOH}$ or cold $0.1 \mathrm{~mol} \mathrm{NaOH} / \mathrm{Na}_{4} \mathrm{P}_{2} \mathrm{O}_{7}$ )

3. Digestion with hot $40 \% \mathrm{HF}$

4. Oxidation with $10 \% \mathrm{KClO}_{3}$ in $35 \% \mathrm{HNO}_{3}$ (dilute Shultze solution (Gray 1965))

5. Extraction with cold 5\% ammonia solution

6. Reacidification with $\mathrm{HCl}$. 
All operations after the initial sieving are carried out in the same $50-\mathrm{ml}$ polypropylene centrifuge tube to minimize contamination introduced in the laboratory (Gillespie \& Hedges 1984), and to allow the use of the hot hydrofluoric acid solution. The alkali solutions remove dark humic materials; several extractions are usually needed, and long centrifuge times are sometimes necessary to spin down all of the fine sediment. One improvement to this scheme might be to perform the hydrofluoric acid digestion before the alkali extraction, since destruction of clay minerals and clay-organic complexes makes the alkali treatment more effective, and centrifugation is faster with the clays removed. Silicates are destroyed in the HF digestion stage, the most significant loss occurring during the first hour of heating in a boiling water bath. Caution is necessary for this step, because some samples react very violently - slow addition of HF, gentle stirring and a resting period to allow any initial reaction to subside should precede heating. For sediments containing calcium or aluminum, it is advantageous to add $10 \%$ hydrochloric acid to the hydrofluoric acid solution to avoid precipitation of insoluble fluorides. Oxidation with dilute Schultze solution may also be quite vigorous, requiring similar caution, and no heating is normally required. This oxidation reagent is stronger than the hypochlorite bleach used for the New Zealand sequence above, but does not oxidize pollen. The Schultze oxidation releases more dark humic material; this can be extracted with any alkaline solution, the 5\% ammonia solution used here is effective, simple to prepare and volatile.

Pretreated samples were combusted in evacuated and sealed quartz tubes with copper II oxide and silver wire. The purified $\mathrm{CO}_{2}$ was then converted to graphite, following a method developed by Lowe and Judd (1987). Sample $\mathrm{CO}_{2}$ is introduced with hydrogen into a quartz reaction vessel containing finely divided iron powder. At $700^{\circ} \mathrm{C}$, the $\mathrm{CO}_{2}$ is reduced to graphite, which is deposited on the iron catalyst. This mixture is pressed into a copper target holder for insertion into the AMS system. All graphite targets were measured in the Nuclear Sciences Group (INS) AMS facility in the same way (Wallace et al. 1987). The sample ${ }^{14} \mathrm{C}$ count rates, normalized to the ${ }^{13} \mathrm{C}$ currents, were compared with the normalized count rate from a target prepared from the NBS oxalic acid modern standard. Measurement of each sample target was broken into three runs of 10 min each, with the standard counted at the beginning, middle and end of each sequence. Any drift in the system could be detected and compensated for, during this procedure. Experimental errors assigned to the results are based on counting statistics, with an extra term to account for any nonstatistical scatter indicated by applying a chi-square test to the measured values.

In calculating the ${ }^{14} \mathrm{C}$ ages of the samples, the ${ }^{14} \mathrm{C}$ count rates were corrected for the different natural carbon isotopic abundances in samples and standard (using $\delta^{13} \mathrm{C}$ values from separate measurements on the same $\mathrm{CO}_{2}$ used to prepare the graphite target), and then normalized to $\delta^{13} \mathrm{C}$ $=-25 \%$ for samples, and $\delta^{13} \mathrm{C}=-19 \%$ for the modern standard. Dates reported are conventional ${ }^{14} \mathrm{C}$ ages, as defined by Stuiver and Polach (1977), based on the Libby half-life of 5568 years.

\section{RESULTS AND DISCUSSION}

Taking the series of chemically separated fractions, processed at Lincoln University, from Profiles 5 and 7 (Table 1), all acid-soluble preparations yield ages younger than that of an untreated sample $(12.57 \pm 0.37 \mathrm{ka} \mathrm{BP}, \mathrm{NZA}-262)$. The fraction insoluble in $6 \mathrm{~mol} \mathrm{HCl}$ is the same age as the untreated sample, indicating that there is little protein or other easily hydrolyzed organic component in the sediment. The fraction soluble in organic solvents (NZA-239) is older than the untreated sample, but still considerably younger than $22.6 \mathrm{ka}$, the presumed age of the tephra deposition. In this series, the oldest dates are obtained on the residue after hydrolysis/oxidation with $70 \%$ nitric acid, which has previously been an effective pretreatment for soil organic matter in peats (Goh 1978). Hammond et al. (1991) have discussed the significance of the other dates in this series. 
TABLE 1. AMS Dates From Graham's Terrace, Profiles 5 and $7 *$

\begin{tabular}{|c|c|c|c|c|}
\hline Lab no. & Location & Fraction dated & $\delta^{13} \mathrm{C}$ & Age BP \\
\hline NZA-264 & P5, 0-5 cm below tephra & $0.1 \mathrm{~mol} \mathrm{HCl} / 0.3 \mathrm{~mol} \mathrm{HF}$ soluble & & $5975 \pm 250$ \\
\hline NZA-258 & P5, 0-5 cm below tephra & $\begin{array}{l}\text { Fulvic acid, extracted with } \\
0.1 \mathrm{~mol} \mathrm{NaOH} / 0.1 \mathrm{~mol} \mathrm{Na} \mathrm{P}_{2} \mathrm{O}_{7}\end{array}$ & & $7770 \pm 265$ \\
\hline NZA-256 & P5, 0-5 cm below tephra & $6 \mathrm{~mol} \mathrm{HCl}$ soluble & -27.1 & $8710 \pm 300$ \\
\hline NZA-287 & P5, 0-5 cm below tephra & $70 \% \mathrm{HNO}_{3}$ soluble & -26.5 & $12,080 \pm 345$ \\
\hline NZA-271 & P5, $0-5 \mathrm{~cm}$ below tephra & Residue after $6 \mathrm{~mol} \mathrm{HCl}$ & -28.5 & $12,525 \pm 170$ \\
\hline NZA-262 & P5, $0-5 \mathrm{~cm}$ below tephra & Untreated & & $12,565 \pm 365$ \\
\hline NZA-327 & P7, 0-5 cm above tephra & $\begin{array}{l}\text { Residue after hot } 1 \mathrm{~mol} \mathrm{HCl} \text {, } \\
0.1 \mathrm{~mol} \mathrm{NaOH} / 0.1 \mathrm{~mol} \mathrm{Na}_{42} \mathrm{O}_{7}\end{array}$ & -28.6 & $14,410 \pm 215$ \\
\hline NZA-239 & P5, 0-5 cm below tephra & $\begin{array}{l}\text { Lipids, extracted with the solvent } \\
\text { sequence: acetone, petroleum spirit } \\
\text { ethanol/benzene, methanol/chloroform }\end{array}$ & & $15,205 \pm 240$ \\
\hline NZA-335 & P5, $0-5 \mathrm{~cm}$ below tephra & $\mathrm{NZ}$ pollen preparation (see text) & -28.3 & $15,240 \pm 510$ \\
\hline NZA-325 & P7, 0-5 cm below tephra & $\begin{array}{l}\text { Residue after hot } 1 \mathrm{~mol} \mathrm{HCl} \text {, } \\
0.1 \mathrm{~mol} \mathrm{NaOH} / 0.1 \mathrm{~mol} \mathrm{Na}_{4} \mathrm{P}_{2} \mathrm{O}_{7}\end{array}$ & -28.5 & $15,490 \pm 250$ \\
\hline NZA-371 & P5, $0-5 \mathrm{~cm}$ above tephra & Residue after $70 \% \mathrm{HNO}_{3}$ & -26.7 & $15,540 \pm 240$ \\
\hline NZA-909 & P5, $0-5 \mathrm{~cm}$ above tephra & $\begin{array}{l}\text { Repeat of NZA-371 after second treatment } \\
\text { with } 70 \% \mathrm{HNO}_{3}\end{array}$ & -29.7 & $16,740 \pm 230$ \\
\hline NZA-270 & P5, $0-5 \mathrm{~cm}$ below tephra & $\begin{array}{l}\text { Residue after } 0.1 \mathrm{~mol} \mathrm{HCL} / 0.3 \mathrm{~mol} \mathrm{HF} \text {, } \\
0.1 \mathrm{~mol} \mathrm{NaOH} / 0.1 \mathrm{~mol} \mathrm{Na} \mathrm{P}_{2} \mathrm{O}_{7}\end{array}$ & -28.7 & $17,515 \pm 460$ \\
\hline NZA-263 & P5, 0-5 cm below tephra & Residue after $0.1 \mathrm{~mol} \mathrm{NaOH} / 0.1 \mathrm{~mol} \mathrm{Na}_{4} \mathrm{P}_{2} \mathrm{O}_{7}$ & & $17,900 \pm 335$ \\
\hline NZA-293 & P5, 0-5 cm below tephra & Residue after $70 \% \mathrm{HNO}_{3}$ & -30.2 & $18,810 \pm 380$ \\
\hline NZA-373 & P7, 0-5 cm below tephra & Residue after $70 \% \mathrm{HNO}_{3}$ & -28.8 & $19,170 \pm 480$ \\
\hline NZA-372 & P5, $50 \mathrm{~cm}$ below tephra & Residue after $70 \% \mathrm{HNO}_{3}$ & -26.7 & $20,670 \pm 470$ \\
\hline
\end{tabular}

*Samples pretreated at Lincoln University, New Zealand, by Hammond and Goh.

For the samples processed at ANU from $5 \mathrm{~cm}$ above and below the tephra layer in Profile 4B (Table 2), we observe the same younger ages for acid- or alkali-soluble fractions, but the oldest fraction (NZA-323: $21 \mathrm{ka}$ ) is now the residue after the full sequence of alkali extraction, hydrofluoric-acid digestion, chlorate oxidation and a second alkali extraction. Investigations on other sites (Gillespie 1990; Gillespie et al. 1992) have shown that the second alkali extraction removes humic-type material solubilized by the oxidation treatment, and which is similar in age to the standard humic-acid fraction. Residues were examined microscopically and at $400 x$ magnification. It is clear that hot $70 \%$ nitric acid destroys pollen and other non-charred botanical debris, whereas the $35 \%$ nitric acid $/ 10 \%$ potassium chlorate solution, when used at room temperature, leaves most pollen intact. Neither oxidant destroys the fine-grained black material, although a significant amount of carbon is lost with both reagents. Samples over- or underlying the tephra, from Profiles 4B, 5 and 7, were treated with hot $70 \%$ nitric acid, followed by cold 6 mol nitric acid. Material soluble in this reagent gave 12,080 $\pm 345 \mathrm{BP}$ (NZA-287), an age almost identical to the untreated material. The insoluble fractions range in age from $15,540 \pm 240$ to $19,635 \pm 330 \mathrm{BP}(\mathrm{NZA}-293,-329,-371$, and -373). Goh (1991) has shown that this reagent gives maximum ages for buried soils and sediments, whereas the ages at this site are inconsistent. However, the maximum date overlaps with that from the full sequence (with chlorate oxidation) on the same material. The alkali extraction of humic acid is not carried out in the $70 \%$ nitric-acid treatment, which probably accounts for the younger, more variable ages on fractions insoluble in this reagent. For those with appropriate laboratory facilities, the full sequence of extractions has several attractions. The 70\% nitric-acid treatment is simpler to perform and useful for fieldworkers.

We have a conceptual problem with this "black stuff" - we have not positively identified it as charcoal at Graham's Terrace, although it is convenient to think of it in this way. In some sedi- 
TABLE 2. AMS Dates From Graham's Terrace Profile 4B*

\begin{tabular}{|c|c|c|c|c|}
\hline Lab no. & Location & Fraction dàted & $\delta^{13} \mathrm{C}$ & Age BP \\
\hline NZA-248 & Tephra layer & $\begin{array}{l}\text { Cellulose, after } \mathrm{NaClO}_{2} / \mathrm{HCl} \text { bleach of } \\
\text { fibrous material seived out }\end{array}$ & -27.2 & $10,485 \pm 810$ \\
\hline NZA-238 & $0-5 \mathrm{~cm}$ above tephra & $\begin{array}{l}\text { Humic acid, extracted with } \\
0.1 \mathrm{~mol} \mathrm{NaOH} / 0.1 \mathrm{~mol} \mathrm{Na} \mathrm{P}_{4} \mathrm{O}_{7}\end{array}$ & & $11,265 \pm 175$ \\
\hline NZA-328 & $0-5 \mathrm{~cm}$ above tephra & Untreated & -28.2 & $11,870 \pm 120$ \\
\hline NZA-232 & Tephra layer & $\begin{array}{l}\text { Humic acid, extracted with } \\
0.1 \mathrm{~mol} \mathrm{NaOH} / 0.1 \mathrm{~mol} \mathrm{Na} \mathrm{P}_{4} \mathrm{O}_{7}\end{array}$ & & $12,170 \pm 160$ \\
\hline NZA-234 & Tephra layer & $\begin{array}{l}\text { Residue after hot } 1 \mathrm{~mol} \mathrm{HCl} \\
0.1 \mathrm{~mol} \mathrm{NaOH} / 0.1 \mathrm{~mol} \mathrm{Na} \mathrm{P}_{2} \mathrm{O}_{7}\end{array}$ & -28.3 & $12,685 \pm 210$ \\
\hline NZA-241 & Tephra layer & $\begin{array}{l}\text { Residue after } 0.1 \mathrm{~mol} \mathrm{NaOH} / 0.1 \mathrm{~mol} \mathrm{Na}_{4} \mathrm{P}_{2} \mathrm{O}_{7} \text {, } \\
40 \% \mathrm{HF}, 35 \% \mathrm{HNO}_{3} / 10 \% \mathrm{KClO}_{3}, \mathrm{NH}_{3}\end{array}$ & -29.5 & $15,780 \pm 370$ \\
\hline NZA-236 & $0-5 \mathrm{~cm}$ below tephra & $\begin{array}{l}\text { Humic acid, extracted with } \\
0.1 \mathrm{~mol} \mathrm{NaOH} / 0.1 \mathrm{~mol} \mathrm{Na} \mathrm{P}_{2} \mathrm{O}_{7}\end{array}$ & & $16,025 \pm 210$ \\
\hline NZA-329 & $0-5 \mathrm{~cm}$ above tephra & Residue after $70 \% \mathrm{HNO}_{3}$ & -30.3 & $19,635 \pm 330$ \\
\hline NZA-247 & $0-5 \mathrm{~cm}$ above tephra & $\begin{array}{l}\text { Residue after } 0.1 \mathrm{~mol} \mathrm{NaOH} / 0.1 \mathrm{~mol} \mathrm{Na}_{4} \mathrm{P}_{2} \mathrm{O}_{7} \text {, } \\
40 \% \mathrm{HF}, 35 \% \mathrm{HNO}_{3} / 10 \% \mathrm{KClO}_{3}, \mathrm{NH}_{3}\end{array}$ & -28.5 & $20,240 \pm 450$ \\
\hline NZA-323 & $0-5 \mathrm{~cm}$ below tephra & $\begin{array}{l}\text { Residue after } 0.1 \mathrm{~mol} \mathrm{NaOH} / 0.1 \mathrm{~mol} \mathrm{Na}_{4} \mathrm{P}_{2} \mathrm{O}_{7} \text {, } \\
40 \% \mathrm{HF}, 35 \% \mathrm{HNO}_{3} / 10 \% \mathrm{KClO}_{3}, \mathrm{NH}_{3}\end{array}$ & -28.9 & $21,010 \pm 395$ \\
\hline
\end{tabular}

*Samples pretreated at the Australian National University by Gillespie

ments, it is charcoal and has a similar size range to pollen (Clark 1983). For other sediments, such as the ones we used here, the black particles are smaller (generally $<10 \mu \mathrm{m}$ ), and require further study to determine their origin and structure. However, both the pollen and the black particles probably arrive in the sediments by similar processes (notably wind or water deposition) at similar times, and the black particles are certainly very resistant to chemical attack.

We have not been able to obtain maximum dates for the tephra layer, itself, because it does not appear to contain the same quantity of residual fine charcoal as the peaty soils over- and underlying it. The tephra layer does, however, contain some probable root material and the same amount of soluble humic material as the peaty soils above and below it. Both of these fractions gave a falsely young age for the deposit.

Questions remain about the different approaches to dating tephra and other deposits with little carbon. Campbell (1986) obtained dates of 21,300 \pm 450 (NZA-7144) and 21,300 \pm 460 (NZA7373) for peat over- and underlying the Kawakawa Tephra at Howard's River, near Nelson, using gas proportional radiometric ${ }^{14} \mathrm{C}$ with minimal pretreatment (acid wash only), whereas AMS dates obtained by one of us (A.P.H.), using the $70 \%$ nitric-acid pretreatment on samples from the same sampling intervals as Campbell, gave 18,920 \pm 420 (NZA-907) and 19,660 \pm 280 (NZA-908). These two sets of data are significantly different, and the samples given a supposedly good pretreatment are younger than untreated samples. Several possible reasons for this difference remain unexplored:

1. Calibration and background subtraction procedural differences between the radiometric and AMS laboratories, which could invalidate the comparisons

2. Unaccounted laboratory contamination introduced during the pretreatment of AMS samples, which may add modern carbon to the measured sample

3. Incomplete combustion of low-carbon samples, which could result in a bias toward the younger, more volatile components not removed during pretreatment, and perhaps most likely, 
4. Difficulties of association of samples with the event to be dated when the site is remote from that event (subsequent AMS dating of the same samples dated radiometrically by Campbell gave 20,490 \pm 340 and 21,040 $\pm 335 \mathrm{BP}$ ) (Table 3).

TABLE 3. Other Dates From Kawakawa Tephra Sites*

\begin{tabular}{|c|c|c|c|c|}
\hline Lab no. & Location & Fraction dated & $\delta^{13} \mathrm{C}$ & Age BP \\
\hline $\begin{array}{l}Q-2665 \text { to } \\
Q-2668\end{array}$ & $\begin{array}{l}\text { Within ignimbrite } \\
\text { at four sites near } \\
\text { source of eruption }\end{array}$ & $\begin{array}{l}\text { Acid- and alkali-washed charred wood } \\
\text { (pooled mean of four determinations) }\end{array}$ & -23.2 & $22,590 \pm 230$ \\
\hline NZ-7373 & Above tephra & Peat, acid-washed & -28.1 & $21,300 \pm 460$ \\
\hline NZA-2066 & & AMS date on same sample & & $21,040 \pm 335$ \\
\hline NZ-7144 & Below tephra & Peat, acid-washed & -27.4 & $21,300 \pm 450$ \\
\hline NZA-2067 & & AMS date on same sample & & $20,490 \pm 340$ \\
\hline NZA-908 & Below tephra & Peaty soil after $70 \% \mathrm{HNO}_{3}$ & -29.8 & $18,920 \pm 420$ \\
\hline NZA-907 & Above tephra & Peaty soil after $70 \% \mathrm{HNO}_{3}$ & -29.6 & $19,660 \pm 280$ \\
\hline NZ-6557 & Below tephra & Acid washed fine sandy loam & - & $15,600 \pm 250$ \\
\hline
\end{tabular}

*Q-dates on charred wood from North Island sites, NZ dates on peat from Howard's River, South Island, discussed by Wilson, Switsur and Ward (1988); NZA dates from same Howard's River site, pretreated by Hammond

\section{CONCLUSIONS}

The commonly used acid/base/acid extraction techniques for removing contaminants before ${ }^{14} \mathrm{C}$ dating of soils do not yield acceptable dates for the sediments in the Graham's Terrace sequence. Maximum ages are only obtained by treatment with hot $70 \%$ nitric acid, or with a more complicated sequence involving chlorate oxidation. Although the samples contain $4-5 \%$ organic carbon, most of this is present as younger contaminants, particularly humic materials, which, in these fine-grained sediments, are resistant to the standard pretreatment methods. Some mineral destruction seems to be necessary to remove organic material associated with the fine silt/clay fraction, before oxidation can have the desired effect of rendering soluble the alkali-resistant humic carbon. Given these findings, it was possible to achieve dates within a few percent of the known age defined by measurements on well-preserved, uncontaminated charred wood. Because there are good reasons why we would expect dates on soil or peat organic components to be younger than equivalent charcoal, we view this as a significant success. The concept of dating silt-sized charcoal and pollen has the potential to provide reasonable ages for fine-grained sediments containing very little carbon, and is being further explored at other sites in alluvial, lacustrine and aeolian environments (Gillespie 1990; Gillespie et al. 1991, 1992).

\section{ACKNOWLEDGMENTS}

The authors would like to express their appreciation to Jim Caldwell, Jon Luly and Gillian Jemmett of the Department of Biogeography and Geomorphology, ANU, for technical assistance and advice on pollen recovery methodology, and to John Chappell of ANU, Bernie O'Brien and Martin Manning of INS for management of this joint project. 


\section{REFERENCES}

Bailey, J. M. and Lee, R. 1972 The effect of alkaline pretreatment on the radiocarbon dates of several New Zealand charcoals. In Grant-Taylor, T. L. and Rafter, T. A., eds., Proceedings of the 8th International ${ }^{14} \mathrm{C}$ Conference. Wellington, The Royal Society of New Zealand: G46-55.

Bailey, J. M., Lee, R., Rankin, P. C. and Spier, T. W. 1975 Humic acid contamination of charcoals from Quaternary tephra deposits in New Zealand. In Suggate, R. P. and Cresswell, M. M., eds., Quaternary Studies. Wellington, The Royal Society of New Zealand: 53-55.

Campbell, I. B. 1986 New occurrences and distribution of Kawakawa Tephra in South Island, New Zealand. New Zealand Journal of Geology and Geophysics 29: 425-435.

Clark, R. J. 1983 Pollen and charcoal evidence for the effects of aboriginal burning on the vegetation of Australia. Archaeology and Physical Anthropology in Oceania 18: 32-37.

Fowler, A. J., Gillespie, R. and Hedges, R. E. M. 1986 Radiocarbon dating of sediments by accelerator mass spectrometry. Physics of the Earth and Planetary Interiors 44: 15-20.

Gillespie, R. 1990 On the use of oxidation in AMS sample pretreatment. In Yiou, F. and Raisbeck, G. M., eds., Proceedings of the 5 th International Conference on Accelerator Mass Spectrometry. Nuclear Instruments and Methods B52: 345-347.

Gillespie, R. Dlugokencky, E., Sparks, R. J., Wallace, G., Prosser, I. P. and Chappell, J. M. A. 1992 AMS dating of alluvial sediments on the Southern Tablelands of New South Wales. Radiocarbon, this issue.

Gillespie, R. and Hedges, R. E. M. 1984 Laboratory contamination in radiocarbon accelerator mass spectrometry. Nuclear Instruments and Methods 233: 294-296.

Gillespie, R., Magee, J. W., Luly, J. G., Dlugokencky, E., Sparks, R. J. and Wallace, G. 1991 AMS radiocarbon dating in the study of arid environments: Examples from Lake Eyre, South Australia. Palaeogeography, Palaeoclimatology, Palaeoecology 84: 333-338.

Goh, K. M. 1978 Removal of contaminants to improve the reliability of radiocarbon dates of peat. Journal of Soil Science 29(3): 340-349.

1991 Carbon dating. In Coleman, D. C. and Fry, B., eds., Carbon Isotope Techniques. San Diego, Academic Press, Inc.: 125-145.

Goh, K. M. and Molloy, B. J. P. 1972 Reliability of radiocarbon dates from buried charcoals. In GrantTaylor, T. L. and Rafter, T. A. eds., Proceedings of the 8th International Radiocarbon Conference. Wellington, The Royal Society of New Zealand: G29-45.
Goh, K. M., Molloy, B. J. P. and Rafter, T. A. 1977 Radiocarbon dating of Quaternary loess deposits, Banks Peninsular, Canterbury, New Zealand. Quaternary Research 7: 177-196.

Goh, K. M. and Pullar, W. A. 1977 Radiocarbon dating techniques for tephras in central North Island, New Zealand. Geoderma 18: 265-278.

Gray, J. 1965 Extraction techniques. In Kummel, B. and Raup, G., eds., Handbook of Palaeontological Tech. niques. San Francisco, W. H. Freeman \& Co.: 530-587.

Hammond, A. P., Goh, K. M., Tonkin, P. J. and Manning, M. R. 1991 Chemical pretreatments for improving the radiocarbon dates of peats and organic silts in a gley podzol environment, Graham's Terrace, North Westland. New Zealand Journal of Geology and Geophysics 34: 191-194.

Hance, R. L. and Anderson, G. 1963 Extraction and estimation of soil phospholipids. Soil Science 96: 94-98.

Lowe, D. C. and Judd, W. J. 1987 Graphite target preparation for radiocarbon dating by accelerator mass spectrometry. Nuclear Instruments and Methods B28: 113-116.

Mew, G., Hunt, J. L., Froggart, P. C., Eden, D. N. and Jackson, R. J. 1986 An occurrence of Kawakawa Tephra from the Grey Valley, South Island, New Zealand. New Zealand Journal of Geology \& Geophysics 29: 315-322.

Scharpenseel, H. W. 1979 Soil fraction dating. In Berger, R. and Suess, H. E., eds, Radiocarbon Dating. Proceedings of the 9 th International ${ }^{14} \mathrm{C}$ Conference. Berkeley, University of California Press: 279-284.

Schollenberger, C. J. 1945 Determination of soil organic matter. Soil Science 59: 53-56.

Shultz, H. (ms.) 1962 Studies in Radiocarbon Dating. Thesis, Pennsylvania State University, State College, Pennsylvania: 57.

Singh, G., and Geissler, E. A. 1985 Late Cainozoic history of vegetation, fire, lake levels and climate at Lake George, New South Wales, Australia. Philosophical Transactions of the Royal Society of London B311: 379-447.

Stuiver, M. and Polach, H. A. 1977 Discussion: Reporting of ${ }^{14} \mathrm{C}$ data. Radiocarbon 19(3): 355-363.

Wallace, G., Sparks, R. J., Lowe, D. C. and Pohl, K. P. 1987 The New Zealand accelerator mass spectrometry facility. Nuclear Instruments and Methods B28: 124-128.

Wilson, C. J. N., Switsur, V. R. and Ward, A. P. 1988 A new ${ }^{14} \mathrm{C}$ age for the Oruanui (Wairakei) eruption, New Zealand. Geological Magazine 125: 297-300. 